\title{
The Impact of Corporate Governance on Corporate Tax Avoidance in Indonesia
}

\author{
Nurma Gupita Dewi ${ }^{1}$, Siti Alliyah ${ }^{2}$ \\ \{nurmagupita46@gmail.com ${ }^{1}$ \} \\ Sekolah Tinggi Ilmu Ekonomi YPPI Rembang ${ }^{1,2}$
}

\begin{abstract}
Tax is the main source of income in Indonesia which aims to encourage sustainable and equitable economic growth. If the economy runs stably, then economic growth will increase from year to year. This research is based on the rise of tax avoidance phenomenon in Indonesia. Corporate tax avoidance is heavily influenced by several components of corporate governance pressure. The purpose of this research is to look into the impact of company governance on tax evasion. The Corporate Governance Perception Index (CGPI) released by the Indonesian Institute for Corporate Governance (IICG) serves as a proxy for variable corporate governance in this study, whereas tax avoidance variables are quantified by the effective tax rate. The companies included in this study were those that were listed on the Corporate Governance Perception Index between 2013 and 2017. Purposive sampling criteria and regression linier analysis were utilized in this study. The findings revealed that corporate governance had a favorable and considerable impact on tax evasion.
\end{abstract}

Keywords: Corporate governance, corporate governance perception index, tax avoidance

\section{Introduction}

Tax evasion has become a hot topic in political and academic debates [1][2], and more recent studies have looked at the consequences of tax evasion, including economic consequences [3]. Taxes are the primary source of revenue for governments and one of the most significant costs for businesses. Tax revenue's share to domestic income increased from 75.2 percent in 2013 to 81.2 percent in 2017. Tax collections increased by an average of 6.5 percent every year from 2013 to 2017, with a contribution of 79.3 percent [4]. Several factors influenced the growth of tax revenue during this period, including the relative improvement in the global and domestic economy, the ongoing tax administration and service reform program, improvement and refinement of the taxation technology and information (IT) system, the Tax Amnesty (TA) program, and improvement of tax regulations [4].

Collecting taxes are a fundamental way for countries to generate public revenues that make it possible used to welfare of society, like infrastructure and the provision of services. Therefore, the state makes tax laws including Tax Law No. 36 of 2008. The purpose of the law to collect taxes for citizens is to obtain maximum state income from taxes. However, in reality, gaps appear in the tax law, making tax avoidance practice often carried out by taxpayers in order to avoid their obligation to pay taxes. Tax evasion is a strategy for lowering the tax burden or the amount of corporate tax owed. Tax evasion, according to Wang et al. [3] entails a corporation keeping monetary resources that would otherwise go to the government within the company. 
The implementation of good governance is needed to minimize tax avoidance. The implementation of corporate governance aims to guide companies to produce a value added to shareholders over a long period of time, but it still pays attention to the interests of stakeholders in the company [5]. Corporate governance is required to address any conflicts of interest or competing goals among the business's various stakeholders. The implementation of good corporate governance will make agents comply with all existing regulations, including not taking aggressive actions against tax planning.

In recent years, corporate tax dodging has received a lot of media attention. In recent years, the growing focus on improper tax avoidance has sparked a lot of interest in the subject outside of the tax world [6]. The findings of studies into the impact of the relationship between corporate governance and tax evasion are still mixed. Corporate governance has a strong favorable effect on tax avoidance, according to the findings of Kovermann and Velte [2] and Tahar and Rachmawati [7]. Corporate governance procedures, according to Mapadang [8,] had a detrimental impact on tax avoidance, however Armstrong, et al. [9] and Syuhada, et al. [10] found that effective corporate governance, as represented by various corporate governance mechanisms, had no significant impact on tax avoidance. The goal of this research is to confirm the impact of company governance on tax evasion.

\section{Method}

This study is a type of quantitative research, which is defined as research that focuses on evaluating theories through the collection of data [3]. Observation of secondary data through gathering data and literature related to the subject under investigation collected from the Indonesia Stock Exchange and the Indonesian Institute for Corporate Governance (IICG) websites for the period 2013-2017 were used as data collection strategies. The direction of the link between the dependent variable and the independent variable is shown in this study using multiple regression analysis approaches [14].

\subsection{Dependent variable}

Tax avoidance is the dependent variable in this study, which is proxied by cash effective tax rates. The current tax paid by the corporation in compliance with the regulations of taxation on taxable income was used to calculate CETR [11].

$$
\mathrm{CETR}=\frac{\text { Tax Expense }}{\text { Pretax Income }}
$$

\subsection{Independent variable}

The Corporate Governance Perception Index (CGPI), which has a value of 1-100, is a proxy for corporate governance. The CGPI is a research and ranking program conducted by the IICG on the application of corporate governance in Indonesia (The Indonesian Institute for Corporate Governance). The Corporate Governance Perception Index [12] assesses three aspects:

a. The compliance part entails adhering to numerous lawsuits and rules imposed by the regulator. 
b. The compliance component of implementation refers to the acceptability of the company's policies and activities in light of accepted standards, ethics, and values.

c. The achievement of the organization in terms of ethical and dignified business operations is the performance component of adopting corporate governance.

\subsection{Control variable}

Variable profitability and firm size used as control variable in that used in this research. The natural logarithm of total assets is used to determine the size of a company. Because ROA can demonstrate management's ability to generate profits, it is utilized as a profitability proxy [13].

$$
\text { Return on Assets }=\frac{\text { Net Income }}{\text { Total Asset }} \times 100
$$

The research sample in this study consists of 62 public companies participating in Corporate Governance Perception Index during period 2013 until 2017. The determination of the companies to be sampled was carried out by using the purposive sampling method. The criteria used were as follows Table 1.

Table 1. Sample Determination

\begin{tabular}{lllllll}
\hline Sample Criteria & $\mathbf{2 0 1 3}$ & $\mathbf{2 0 1 4}$ & $\mathbf{2 0 1 5}$ & $\mathbf{2 0 1 6}$ & $\mathbf{2 0 1 7}$ & \\
\hline $\begin{array}{l}\text { Public companies participating in CGPI } \\
\text { during the 2013-2017 period }\end{array}$ & 16 & 12 & 15 & 15 & 13 & 71 \\
$\begin{array}{l}\text { The company did not earn negative } \\
\text { profits during the observation period }\end{array}$ & & & & & (9) \\
\hline Total & & & & & & \\
\hline
\end{tabular}

\section{Results and Discussions}

\subsection{Descriptive statistics}

Descriptive statistical (Table 2) analysis is an analysis used to provide an overview or description of the observed research variables [14].

Table 2. Descriptive Statistics Result

\begin{tabular}{llllll}
\hline Variable & N & Minimum & Maximum & Mean & Std. Deviation \\
\hline CGPI & 62 & 69,72 & 93,86 & 85,9166 & 4,31044 \\
Size & 62 & 15,01 & 20,84 & 18,4115 & 1,70722 \\
ROA & 62 & 0,14 & 20,68 & 4,5456 & 4,82331 \\
CETR & 62 & 0,108 & 0,727 & 0,26094 & 0,105181 \\
\hline
\end{tabular}

Based on Table 2, it can be seen that tax avoidance as dependent variable, which is proxy by cash effective tax ratio (CETR) with a minimum of 0,727 and a maximum of 0,108 , and an average of 0,26094 . This result shows that the companies that are observed tend to have low 
average tax avoidance, because it is less than $50 \%$. Meanwhile, the corporate governance variable served as a proxy, with a maximum value of 93,86 and a minimum value of 69,72 . The average value of 85,9166 indicates that the majority of the companies sampled in this study fall into the category of most trusted corporations in the CGPI.

\subsection{Result}

Table 3. Hypothesis Result

\begin{tabular}{llll}
\hline Variable & Coefficient & T & Sig. \\
\hline (Constant) & 0,492 & 2,283 & 0,026 \\
CGPI & 0,010 & 2,792 & 0,007 \\
SIZE & $-0,056$ & $-5,941$ & 0,000 \\
ROA & $-0,009$ & $-3,690$ & 0,000 \\
Adjusted R Square & 0,381 & & \\
F & 13,534 & & \\
\hline
\end{tabular}

The result of multiple linear regression analysis in this research can be seen in Table 3 and obtained multiple linear regression equation as follows:

$$
\mathrm{CETR}=0,492+0,010 \mathrm{CGPI}-0,056 \mathrm{SIZE}-0,009 \mathrm{ROA}+\varepsilon
$$

\subsection{Discussion}

According to the results in Table 3 , the coefficient value $=0.010$ with a significance level of 0.007 less than 0.05 indicates that corporate governance has a positive and statistically significant effect on tax avoidance. This means that good corporate governance will ensure that agents adhere to all applicable regulations, including refraining from aggressive tax planning. The greater the CETR value, the less corporate tax avoidance there is. CETR is based on a number-based tax amount and reflects actual rates on a mandatory tax basis [15]. Taxation is critical in bolstering a country's fiscal revenues, particularly in Indonesia. In comparison, a business, as a taxpayer, views tax as a cost that reduces profits. As a result, the manager's objective is to maximize profit while paying the least amount of tax possible without violating any laws through tax avoidance [11].

Tax avoidance is a term that refers to tax rates that reflect tax planning strategies ranging from tax management to tax planning, aggressive tax planning, tax evasion, and tax sheltering [16]. This research corroborates the findings of Kovermann and Velte [2] and Tahar and Rachmawati [7]. Kovermann and Velte [2] argue that effective corporate governance mechanisms direct tax avoidance to its most advantageous level for each firm. Corporate governance effectiveness can resolve any conflicts of interest or disagreements between various stakeholders.

\section{Conclusion}

The conclusions of this study are as follows. First, tax avoidance can be defined as any activity that reduces a business's tax liability in relation to its pretax income. Agency conflicts may cause the agent to choose a different level of tax avoidance than the principals prefer. As a 
result, corporate governance is required to resolve these issues. Then, the implementation of good corporate governance is generally related to corporate responsibility to ensure a good corporate attitude to protect shareholder requirements including corporate compliance in paying taxes.

\section{Acknowledgement}

This research was supported by Sekolah Tinggi Ilmu Ekonomi YPPI Rembang. We also would like to thank the Institute for Research and Community Services STIE YPPI Rembang.

\section{References}

[1] F. Huseynov, S. Sardarli, and W. Zhang, "Does index addition affect corporate tax avoidance?," Journal of Corporate Finance, vol. 43, pp. 241-259, 2017.

[2] J. Kovermann and P. Velte, "The impact of corporate governance on corporate tax avoidance-A literature review," Journal of International Accounting, Auditing and Taxation, vol. 36, p. 100270, 2019.

[3] F. Wang, S. Xu, J. Sun, and C. P. Cullinan, "Corporate tax avoidance: A literature review and research agenda," Journal of Economic Surveys, vol. 34, pp. 793-811, 2020.

[4] www.fiskal.kemenkeu.go.id.

[5] A. Taman and B. A. Nugroho, "Determinan kualitas implementasi corporate governance pada perusahaan yang terdaftar di bursa efek indonesia (BEI) periode 2004-2008," Jurnal Pendidikan Akuntansi Indonesia, vol. 9, 2011.

[6] L. Oats and P. Tuck, "Corporate tax avoidance: is tax transparency the solution?," Accounting and Business Research, vol. 49, pp. 565-583, 2019.

[7] A. Tahar and D. Rachmawati, "Pengaruh Mekanisme Corporate Governance, Corporate Social Responsibility, Ukuran Perusahaan dan Leverage Terhadap Penghindaran Pajak (Studi Pada Perusahaan Manufaktur yang Terdaftar di Bursa Efek Indonesia Tahun 2015-2017)," Kompartemen: Jurnal Ilmiah Akuntansi, vol. 18, 2020.

[8] A. Mapadang, "Pengaruh Mekanisme Corporate Governance Terhadap Tax Avoidance," Aliansi: Jurnal Manajemen dan Bisnis, vol. 13, pp. 115-120, 2018.

[9] C. S. Armstrong, J. L. Blouin, A. D. Jagolinzer, and D. F. Larcker, "Corporate governance, incentives, and tax avoidance," Journal of Accounting and Economics, vol. 60, pp. 1-17, 2015.

[10] A. Syuhada, Y. Yusnaini, and E. Meirawati, "Pengaruh Good Corporate Governance dan Profitabilitas Terhadap Tax Avoidance (Studi Empiris pada Sektor Pertambangan Yang Terdaftar di BEI)," Akuntabilitas, vol. 13, pp. 127-140, 2019.

[11] V. A. Tandean and W. Winnie, "The Effect of Good Corporate Governance on Tax Avoidance: An Empirical Study on Manufacturing Companies Listed in IDX period 2010-2013," Asian Journal of Accounting Research, 2016.

[12] www.iicg.org.

[13] H. Masnawaty S, "Effect of Profitability and Size Companies on Tax Avoidance in Manufacturing Companies Listed in Indonesia Stock Exchange," KnE Social Sciences, vol. 2019, p. kss. v3i11. 4045, 2019.

[14] I. Ghozali, "Aplikasi Analisis Multivariete IBM SPSS 23," Badan Penerbit Universitas Diponegoro, Semarang, 2016.

[15] S. Warsini, "Peran Kepemilikan Institusional, Kualitas Audit dan Praktik CG Negara dalam Tax Avoidance," Simposium Nasional Akuntansi XIX, pp. 1-20, 2016. 
[16] M. Hanlon and S. Heitzman, "A review of tax research," Journal of accounting and Economics, vol. 50, pp. 127-178, 2010. 